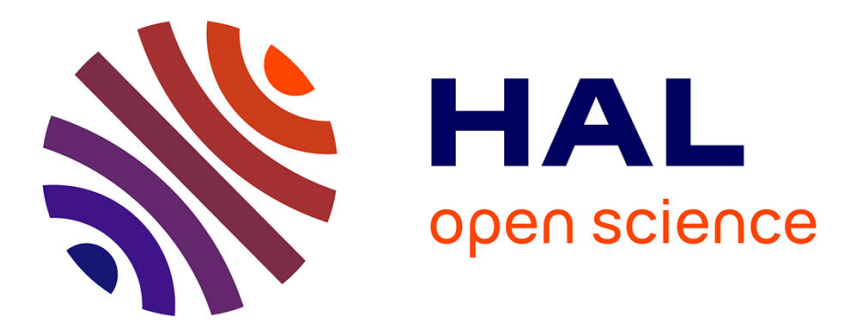

\title{
The ancient rural settlement of Plantades in Salviac (Lot, France): comparison of previous data with two geophysical surveys \\ Michel Dabas, Julien Ollivier
}

\section{- To cite this version:}

Michel Dabas, Julien Ollivier. The ancient rural settlement of Plantades in Salviac (Lot, France): comparison of previous data with two geophysical surveys. Archeosciences, revue d'Archéométrie, 2021, XIVth International Conference of Archaeological Prospection, 45-1, pp.27-30. 10.4000/archeosciences.8319 . halshs-03481552

\section{HAL Id: halshs-03481552 \\ https://shs.hal.science/halshs-03481552}

Submitted on 7 Jan 2022

HAL is a multi-disciplinary open access archive for the deposit and dissemination of scientific research documents, whether they are published or not. The documents may come from teaching and research institutions in France or abroad, or from public or private research centers.
L'archive ouverte pluridisciplinaire HAL, est destinée au dépôt et à la diffusion de documents scientifiques de niveau recherche, publiés ou non, émanant des établissements d'enseignement et de recherche français ou étrangers, des laboratoires publics ou privés. 
The ancient rural settlement of Plantades in Salviac (Lot, France): comparison of previous data with two geophysical surveys.

Michel Dabas*1, Julien Ollivier ${ }^{2}$

${ }^{1}$ AOROC-CNRS-ENS-PSL 45 rue d'Ulm, F-75230 Paris cedex 05

michel.dabas@ens.psl.eu

${ }^{2}$ SRA Occitanie, UMR 5608 TRACES, SRA, 32 rue de la Dalbade - BP 811, F-31080 Toulouse cedex 6

julien.ollivier@culture.gouv.fr

$(*=$ corresponding author $)$

Topic: Case studies and archaeological feedback

Type of presentation: oral

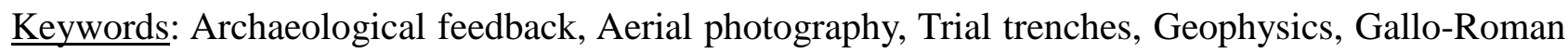
villa.

Highlights: Discovery a rural settlement in the Cadurques territory. Comparison of trial trenches and resistivity and magnetometry maps co-located.

\section{Introduction}

The "Plantades" archaeological site is located close to the small town of Salviac, in the Lot department (France). It is one of the very rare cases of an ancient rural settlement known in the territory of the Gallic tribe of Cadurques, in which less than a dozen examples have been the subject of well-documented excavations (Bouet, 2015; Grimbert et al. 2016). Located at the bottom of the valley on the north-eastern fringe of the Aquitaine Basin, its discovery dates back to only 1987 , when an aerial flight made it possible to discover it during a period of drought through well-defined cropmark anomalies (Fig.1). These images revealed constructions that appear to belong to a GalloRoman villa of the type "with multiple aligned pavilions" (Ferdière et al. 2010).

In 2010, the site was the subject of an archaeological evaluation survey which resulted in 22 trial trenches, but no report was made as to the outcome of this operation. A topographical plan of the remains was nevertheless drawn up and some archaeological material was collected (approximate time period: 2nd c. AD). These gaps in knowledge of the site prompted us to take up the case again. The objective was to draw up a complete inventory before a possible new campaign in the form of 
surveys and/or more extensive excavations. This is why an inventory of available documentation and artefacts was carried out, in parallel with a geophysical prospecting campaign carried out in 2020 by Géocarta company (Paris). This is also a unique opportunity to compare and complement the different pieces of information.

\section{Geophysical Surveys}

Two types of geophysical surveys were undertaken in October 2020. Considering the type of remains, electrical survey was favoured for the detection of walls. As remains of hypocaust were found in 2010, magnetic survey was also used. The surface area to be prospected being large (almost 3 ha), the ARP (Automatic Resistivity Profiling) and AMP (Automatic Magnetic Profiling) methods were set up pulled by a quad-bike. Both surveys were done in half a day using the same topographic base for planimetric positioning (RTK). The electrical maps were obtained by interpolating the apparent electrical resistivity data for the three depths of investigation on a square mesh of $.3 \times .3 \mathrm{~m}$ (Fig. 2). Linear resistant anomalies appear from the depth of investigation of 50 $\mathrm{cm}$, reflecting the fact that the remains are very superficial, as could be assumed in view of the phytological anomalies. Even if the walls were very clear in aerial prospecting, we can notice that the overall plan in particular in the North is better defined by the electrical method. The electrical map for the $1 \mathrm{~m}$ depth shows the clearest plan, minimizing the surface noise likely associated with the spreading of remains by agricultural tillage. This crop noise is more visible on the east and west sides of the surveyed area compared to the central area which was grazed. It is clear that the remains must be less protected in the ploughed areas than in the central part which corresponds to the centre of the settlement.

Magnetic prospecting using an array of 5 sensors (Grad-1000L, Bartington) spaced $50 \mathrm{~cm}$ apart was interpolated on a fine mesh of $0.15 \mathrm{~m}$. The dynamics of the map is wide $(-10$ to $+10 \mathrm{nT} / \mathrm{m})$. The same linear anomalies (Fig. 2) show up thanks to a strong contrast with the surrounding area, therefore favourable to detection. This fact is to be counterbalanced in the central zone where a white noise is superimposed. We were also able to find in the magnetic data some traces of the old 
2010 trial trenches: this also made possible the control of the spatial georeferencing of the plan of the excavations. The two geophysical methods were therefore perfectly complementary and have helped to control the positioning of previous plan of excavations (but discrepancies seem to exist).

\section{Interpretation}

The results of the analysis of i) aerial photographs of 1987, ii) the trial trenches of 2010 and iii) the geophysical survey of 2020 make it possible to draw up a first plan of the settlement (Fig.3). This covered a minimum area of about 1.5 ha, but its boundaries are not all clearly identified, especially in the west where agricultural work is the source of the destruction of built remains. Conventionally in such a context, the constructions are divided into two distinct sets:

The western part, consists of a courtyard framed by a gallery with at least three branches. Within this vast open space $\left(3,500 \mathrm{~m}^{2}\right.$ minimum), the only remains identified is a north-south oriented pipeline which seems to be associated with southern constructions. In this sector, the southern branch of the portico is flanked by a building made up of two large rooms. To the north, several buildings are also attached to the portico. Two rooms stand out clearly, but the discovery of other walls indicates that additional spaces occupied this area. This part of the establishment corresponds to the pars rustica of the villa.

To the East, the second part is more compact and includes a much higher number of constructions that define the residential sector (pars urbana). The main part, located in the extension of the western courtyard, is organized around a peristyle which is something more common in Southern France compared to the North where colonnaded facades and pavilions are encountered. This peristyle serves four wings. If, to the north and to the south, the function of the different spaces is difficult to establish, it seems more or less clear that the west wing served as a monumental entrance and that the east wing housed ceremonial rooms. They are located on the same axis and their plan obeys a rigorous symmetry. These two wings also have equipment that reflects the luxury of the house: the entrance is made up of a first semi-circular space surrounded by a portico, giving access 
to a quadrangular room that could be described as a vestibule. The west wing has several lounges, among which the one located in the axial position was to open directly onto the central garden.

The raison d'être of the other contiguous spaces is undoubtedly to be found in their different orientation, which allowed their use at other times of the year. Against the south wing of the main block, a second peristyle constitutes a new open space, itself extended by at least three rooms forming a final building to the south, which could correspond to a thermal area.

The site of Plantades belongs to a category of sites now well identified in Gaul, the villae "with multiple aligned pavilions" (Ferdière et al., 2010). In most cases, the establishments have an elongated plan organized into two distinct parts, the residential sector and the agricultural sector, made up of pavilions forming two lines of buildings on either side of the courtyard. Another remarkable feature of the establishment is the sigma peristyle that we propose to restore at the level of the western wing of the residential part. It is an architectural form particularly prized in the southwest of Gaul during Late Antiquity, which monumentalizes access to the residential part of the house, the richness of which it somehow prefigures.

The chronology of the site is however based to date only on a few discoveries made in 2010 and devoid of any stratigraphic context. These are in particular ceramic and glass productions as well as some coins dated from the 2 nd and 3 rd c. AD. Targeted surveys would therefore be necessary to clarify these data and better understand this rare example of a rural Cadurques settlement. 


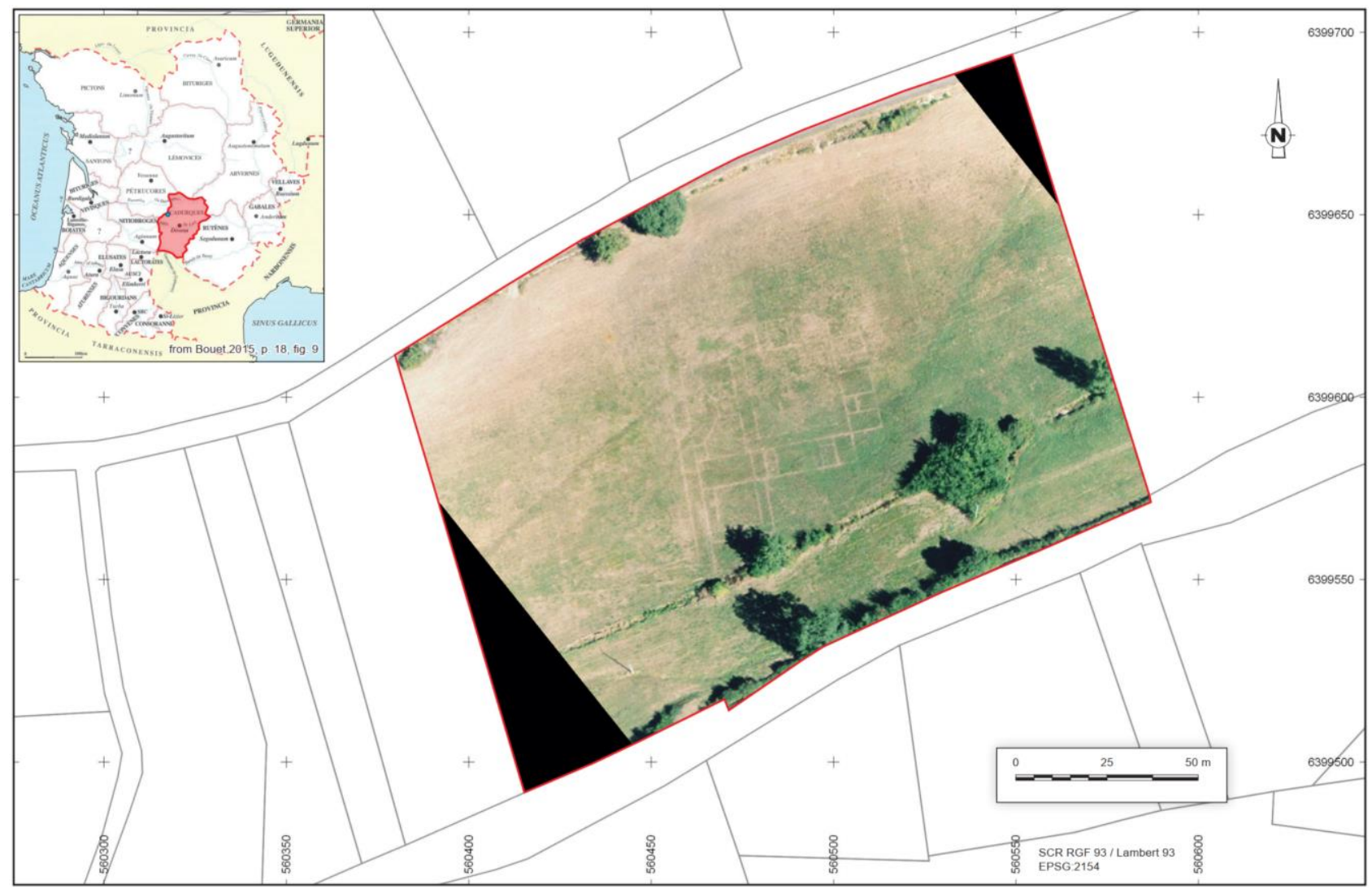

Figure 1: Discovery of the Plantades settlement in 1987. Rectified aerial view showing up negative cropmarks superposed above cadastre (credit: F. Périé). Inset: location of the site - blue dot - within the Gallic tribe of Cadurques - in red- in South-West of France. 


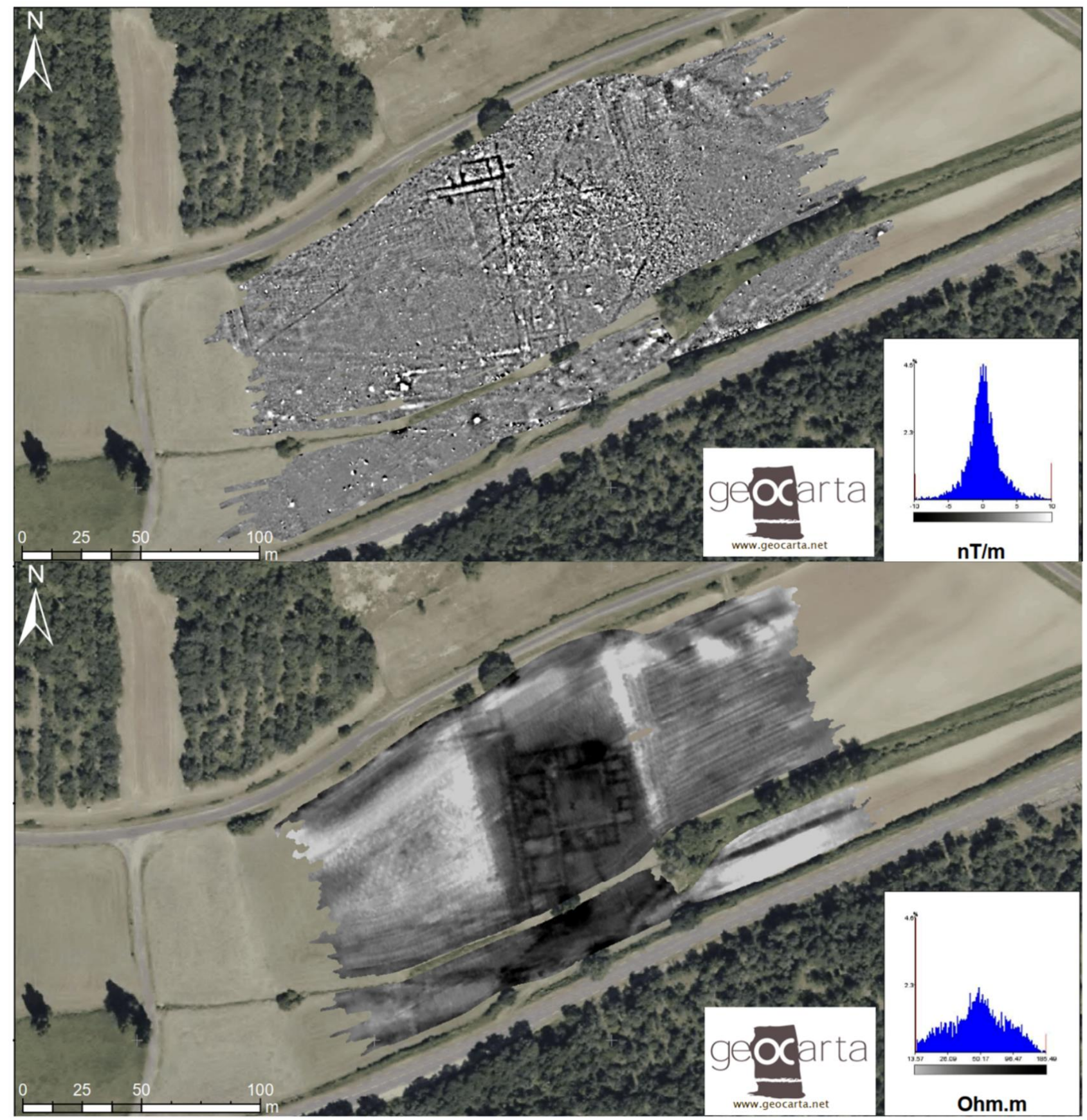

Figure 2: Geophysical Surveys overlaid over vertical aerial photo (IGN). Top: Vertical pseudogradient of the vertical component of the Earth Magnetic Field (5 Bartington Grad-1000L sensors, dynamics $=-10$ to $10 \mathrm{nT} / \mathrm{m}$ ); Above: Resistivity survey (ARP system channel 2 , square array a=1 m; dynamics $=13$ to 185 Ohm.m) (credit: Guillaume Fresse, Frank Muller, Géocarta, Paris). 


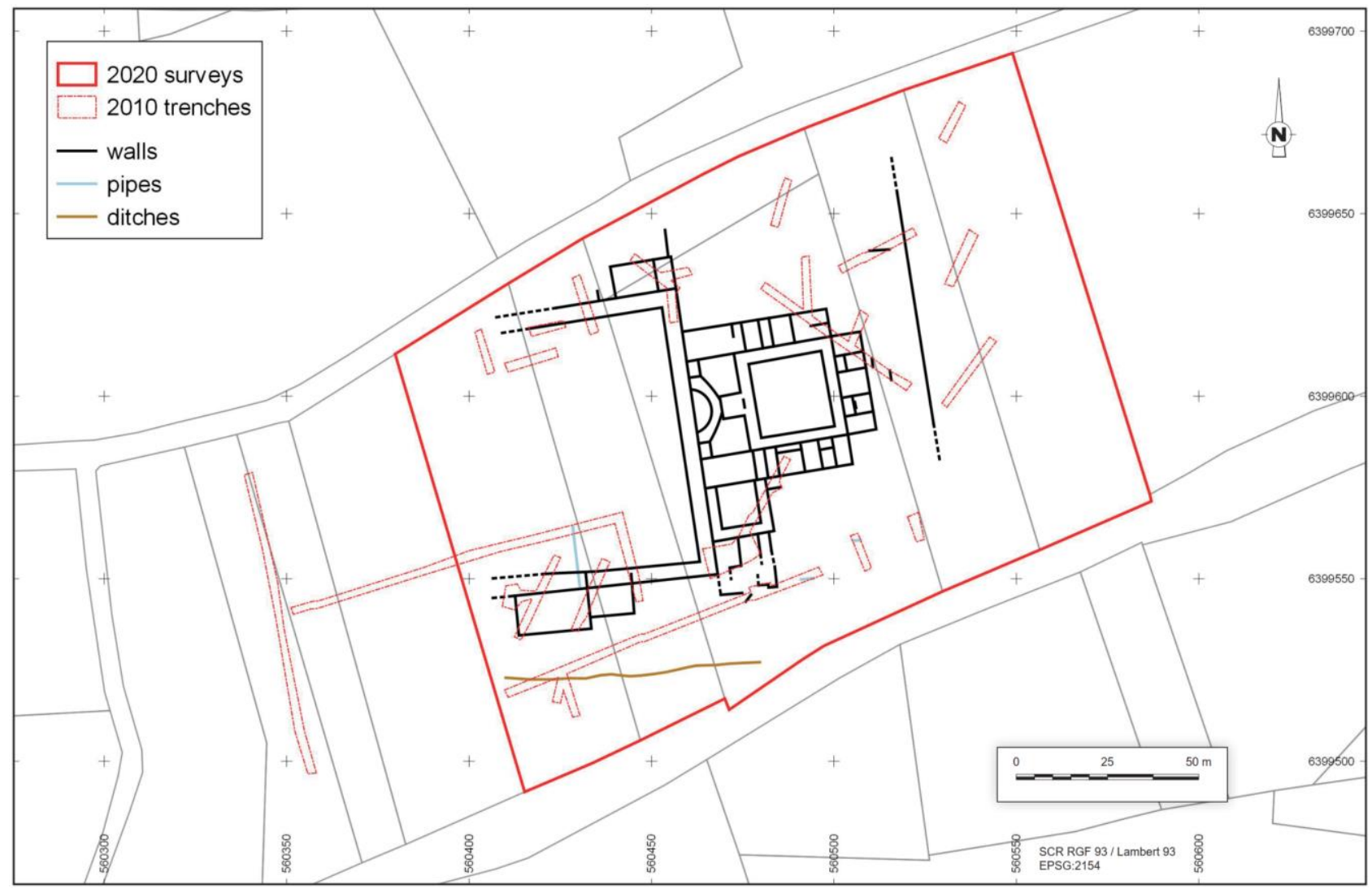

Figure 3: Interpretation of geophysical anomalies (black) superposed with trial trenches opened in 2010 (red) superposed above cadastre (credit: J. Ollivier)

\section{$\underline{\text { References }}$}

Bouet , A., 2015. La Gaule Aquitaine, Paris : Picard. ISBN :978.2.7084.0988.0.

Ferdiere, A., Gandini, C., Nouvel, P., Collart, J.-L., 2010. Les grandes villae "à pavillons multiples alignés" dans les provinces des Gaules et des Germanies : répartition, origine et fonctions, Revue Archéologique de l'Est, 59, (2) : 357-446.

Grimbert, L., MAthe, V., Druez, M., 2016. Pech Piélat (Séniergues, Lot). Un relais routier en pays cadurque, in COLlEONI F. (dir.), Stations routières en Gaule romaine. Architecture, équipements et fonctions, Gallia, 73.1, 91-111. 